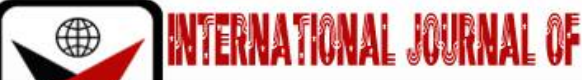

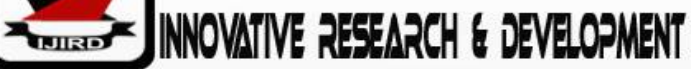

ISSN 2278 - 0211 (Online)

\section{Analysis of Starfruit Farming Based on Tree Ownership Status: Case Study in Depok City, Indonesia}

\author{
Lies Sulistyowati \\ Lecturer, Department of Agricultural Economics, Padjadjaran University, Indonesia \\ Christine Juliana Hakim \\ Undergraduate Student, Department of Agricultural Economics, Padjadjaran University, Indonesia \\ Eti Suminartika \\ Lecturer, Department of Agricultural Economics, Padjadjaran University, Indonesia
}

\begin{abstract}
:
Depok Municipality, Indonesia has established starfruit as a superior commodity and as a city icon. Along with the stipulation, there are many government programs that support starfruit farming business so that it can continue to benefit farmers, in the midst of the issue of the current lagging urban agricultural development. In the business of starfruit farming, found various mastery status of starfruit trees, namely: owners, tenants and sharecroppers. This study aims to analyze starfruit farming based on the ownership status of starfruit trees, and the problems faced in starfruit farming. The research location was in the Laris Jaya II Farmer Group, Mampang Village. The research design used was qualitative with case study research techniques. The data analysis used was income analysis, $\mathrm{R} / \mathrm{C}$ and descriptive analysis.

The results showed that the average net income of starfruit farming in one harvest season was: the highest was the tenant farmer (IDR 3,648,672.00), then the farm owner (IDR 3,611,616.00) and the lowest was the sharecropper (IDR 1,522,116.00). Whereas when viewed from the $\mathrm{R} / \mathrm{C}$, the highest to lowest values were: farm owners (2.23), sharecroppers (2.04), and the lowest were tenant farmers (1.62). The problems faced by farmers based on: a) aspects of production: the difficulty of controlling planthopper pests, limited water discharge during the dry season, and the narrowness of starfruit farming land due to land conversion, b) capital aspects: limited amount of capital, c) marketing aspects: the selling price of starfruit to middlemen is low and the payment system is not cash from joint marketing activities, and d) institutional aspects: PKPBDD marketing institutions that are not operating, no scheduling in groups, and extension activities that are not intensive.
\end{abstract}

Kevwords: Comparative analysis, tree ownership status, starfruit farminq

\section{Introduction}

\subsection{Research Background}

Depok City is one of the municipalities supporting DKI Jakarta with the rate of economic growth dominated by the secondary sector and tertiary sector. Contribution in the agricultural sector is very small and continue to decline, namely 1.68 in 2010, to 1.45 in 2016. (PDRB Kota Depok, 2010-2017). However, these conditions did not discourage the Depok City government from continuing to make various efforts to develop the agricultural sector through various programs and policies. One of the agricultural sector development efforts that has been carried out by the Depok City government is the development of horticulture based on superior commodities. According to Permentan No. 76 of 2012, superior products of horticulture are horticultural products that have potential competitiveness and attention to local wisdom. Starfruit is Depok's superior products of horticulture which has been designated as a city icon by the Mayor of Depok, because it has location-specific values and various advantages. The most popular and widely planted starfruit varieties are Dewa Starfruit. Based on the Decree of the Minister of Agriculture No.:718/ Kpts/ TP.240/ 8/ 98, stated that the Dewa Starfruit is the result of a cross between Bangkok Starfruit and Dewi Starfruit. The superiority of this starfruit includes: its large size (reaching a maximum of $0.8 \mathrm{~kg}$ per fruit), its sweet taste, its even yellowish orange color when it has reached its optimum maturity, and its symmetrical fruit shape. Then, the Dewa Starfruit is also useful to cure various diseases, such as high blood pressure. In Table 1, it can be seen that compared to other cities in West Java, Depok city is the highest center for starfruit production. 


\begin{tabular}{|c|c|c|}
\hline No & Cities & $\begin{array}{c}\text { Starfruit Production } \\
\text { (Quintal) }\end{array}$ \\
\hline 1 & Bogor & 557 \\
\hline 2 & Sukabumi & 14 \\
\hline 3 & Cirebon & 57 \\
\hline 4 & Bekasi & 4351 \\
\hline 5 & Depok & 25176 \\
\hline 6 & Cimahi & 66 \\
\hline 6 & Tasikmalaya & 83 \\
\hline 7 & Banjar & 110 \\
\hline
\end{tabular}

Table 1: Starfruit Production from Various Cities in

West Java, Indonesia

Source: BPS Jawa Barat, 2018

For this reason, there are government programs to achieve the goal of establishing starfruit as a city icon. The various designation objectives are: 1) introducing starfruit products as Depok City icons to the general public and especially the people of Depok City, 2) increasing starfruit production, 3) increasing the income of starfruit farmers, 4) increasing market opportunity access for starfruit farmers and strengthening special institutions for starfruit marketing, and 5) increasing yield processing activities to increase added value.

Pancoran Mas Subdistrict is one of the centers of starfruit planting in Depok City with a total area of starfruit planting of 29.05 Ha (Depok City Agriculture Service, 2018). Furthermore, in this sub-district there are Laris Jaya II Farmers Group who actively accept and participate in various government programs to develop starfruit as an icon of Depok City. According to Mr. Nanang, head of the Depok Starfruit Farmers Association (APEBEDE), this farmer group was formed because the farmers had limited capital to do their farming so that to apply for capital assistance they had to be in groups. In addition, farmers in this farmer group have carried out starfruit farming before the establishment of starfruit as a city icon. So that farmers know the various real efforts of the government in developing starfruit as a city icon and various changes that occur in starfruit farming, especially those that affect their income.

Farmers' income from starfruit farming is also influenced by the price level of starfruit in the market. According to Ms. Karwati, Coordinator of Agricultural Instructor of Depok City, the price of starfruit on the market is fluctuating. This condition occurs when the availability of starfruit in the market is relatively more during the harvest season so that the price of starfruit will decrease. The low starfruit prices are also caused by competition with other fruits on the market. This condition can cause farmers' revenue to fluctuate.

On the other hand, starfruit is said to have high economic value, but as farmers who do farming in urban areas, they experience the problem of high production costs and limited land. So that income from running farming in urban areas will also be limited. Therefore, farmers also farm other commodities or work in the non-agricultural sector with the aim of income maximization.

In the business of starfruit farming, found various mastery status of starfruit trees, namely: owners, tenants and sharecroppers, of course this status difference will have an impact on the income of starfruit farmers. Theoretically, the farm owner can get the highest income, but many other factors affect it. So, this research needs to be done.

However, the establishment of starfruit as an icon of Depok City is expected to significantly improve starfruit farming through various programs and policies of the city government. One success indicator of farming is seen from the income received by farmers from starfruit farming. Then the income from starfruit farming is also expected to maximize the income of farmer families in the midst of more advanced secondary and tertiary sector economic growth in Depok City.

\subsection{Problem Statement}

Based on the phenomenon, this research will try to answer these questions:

- How do you compare the income of star fruit farmers based on the status of starfruit tree ownership

- How much is the contribution of income from star fruit seeds to family income, based on the status of possession of star fruit trees.

- What problems are faced by star fruit farmers to increase their income.

\section{Materials and Methods}

The research design used was qualitative design with case study research techniques. According to Noor (2011), case study research techniques basically study intensively an individual or group that is seen experiencing a particular case.

In line with that, Sugiyono (2008) states that the dominant characteristics of qualitative research are (1) the data source is directly in the form of natural situation data and the researcher is a key instrument, (2) descriptive, (3) more emphasize on process meaning instead of result, (4) analysis of the data is inductive, and (5) meaning is the main concern in the research approach.

The study was conducted at the Laris Jaya II Farmer Group, Mampang Village, Pancoran Mas District, Depok City. The type of data used is primary data from interviews with farmers and secondary data from the Depok City Agriculture Service, BPP Ratu Jaya, and the Depok Starfruit Farmers Association. Then the way to determine the data source is based on census (saturated sampling) because it takes all members of the farmer group to be used as data sources. The data 
collection techniques are observation of participation and direct interviews with starfruit farmers. The analytical method used:

- Income analysis and R/ C:

- Production costs =Fixed costs + Variable costs

- Revenue $=$ Amount of production $x$ Selling price $/$ unit

- Farmer's income $=$ Revenue - Production costs

- R/C $=\frac{\text { Total Revenue }}{\text { Total cost }}$

- Farmers' family income is obtained by summing all the income of farmers and their families from various sources. The source of family income can come from on-farm, off-farm, and non-farm activities (Hernanto, 1988).

- The contribution of farmers' income from starfruit farming is measured in units of percent by formula: $\frac{\text { starfruit farming income }}{\text { total household income }} \times 100 \%$

- Constraints faced by farmers in increasing their income from starfruit farming are analyzed descriptively based on aspects of production, capital, marketing and institutions.

\section{Results and Discussion}

\subsection{Characteristics of Farmers}

Starfruit farmers in the Laris Jaya II Farmers Group have very dynamic characteristics based on: age, level of education, number of family dependents, livelihoods, land area, experience in starfruit farming, tree ownership status and source of labor.

\subsubsection{Age}

According to the BPS category, 80.95 percent of the age of starfruit farmers is in the productive age category (15 - 64 years). The age range of starfruit farmers is from the age of 29 - 75 years. The average age of starfruit farmers is 49 years. So, farmers have an intensive opportunity to increase starfruit farming activities and maximize family income.

\subsubsection{Level of Education}

Starfruit farmers have a relatively low formal education background. The percentage of farmers with a formal education background graduating from elementary school and not graduating is the largest (57.14\%) with an average age of 55.67 years. On the other hand, starfruit farmers have a non-formal educational background by participating in the Starfruit SOP training in 2010. Of the 21 members of the Laris Jaya II Farmers Group, as many as 14 farmers (66.67\%) had participated in the training so that the farmers were said to have knowledge and skills of starfruit farming.

\subsubsection{Number of Family Dependents}

Thirteen members of this farmer group have family responsibilities of 3-4 people. The number of family dependents is related to the source of labor in starfruit farming. If dependents or family members are large, chances are high to be used as labor in the family on starfruit farming. However, some dependents of farmer families are generally still in school, while a number of family members in working age, the majority of whom work outside the agricultural sector. That is because in starfruit farming special skills are needed such as wrapping activities which also require more labor. Because the process of wrapping starfruit which is not right will cause the starfruit to fall out.

\subsubsection{Livelihoods}

The members of this farmer group, besides working as starfruit farmers also do other commodity farming and work outside the agricultural sector. A total of 16 group members stated that farmers as the main occupation and 5 other members stated that farmers were a side job. According to the five members, the income as a farmer is smaller than the income from other jobs outside the agricultural sector so it is classified as a side livelihood. The main types of work outside the agricultural sector of the 5 members of the farmer group are as many as one security guard, two construction workers, and two school guards.

Furthermore, to increase family income, group members who have a primary livelihood as farmers also work outside the agricultural sector such as cake sellers, fruit traders, and construction workers. In addition, family members (wives and children) from farmers have livelihoods as private employees, teachers, cake sellers, housemaids, freelancers, and security guards.

\subsubsection{Experience in Starfruit Farming}

The experience of doing farming is needed to improve skills and expertise in determining various appropriate actions in achieving successful farming. The majority of starfruit farming experiences owned by farmers are more than 12 years (61.93 percent), although the average age of trees owned by farmers has only reached 10.67 years. But before doing the farming alone, these farmers have been involved in starfruit farming as farm laborers or continuing family farming.

\subsubsection{Land Area}

The area of land owned by farmers who are members of this farmer group tends to decrease due to land conversion. So that it will affect the amount of farmers' income from the amount of starfruit produced each harvest season. As many as 
95.24 percent of farmers own land under 0.5 hectares and the average area of starfruit cultivated by farmers in this farmer group is 0.21 hectares.

\subsubsection{Tree Ownership Status}

The status of farmers based on the ownership of starfruit trees is divided into three, namely owners, tenants, and sharecroppers. Based on the mastery status of the starfruit tree, there were 15 farm owners, 3 tenant farmers, and 3 sharecroppers with 39 trees, 53 trees and 40 trees each.

The number and system of tree lease payments from the three tenant farmers is different, which is also because the number of trees rented is different. Payment for each tree is IDR 1,000,000/ year/ 50 trees, IDR 2,500,000/ three years/ 51 trees and IDR 3,000,000/ five years/ 20 trees. Furthermore, the number of profit sharing in the system of trees sharecrop in starfruit farming also varies based on agreements between sharecroppers and farm owners. The percentage of the profit-sharing system agreed to be paid by sharecroppers to farm owner is 25 percent, 40 percent or 60 percent. This form of profit sharing is in the form of cash from the sale of starfruit. The difference in the division of the percentage of profit sharing to tree owners is because the sharecroppers do not pay for taxes or rent. In addition, there is also the expenditure of wages for labor paid by tree owners.

Jiancai Pi (2013), stated that the revenue sharing in sharecropping contracts is 50:50, it is fair and efficient to implement. This is because tree owners also have to pay for land taxes, as well as efforts to maintain their fertility rates. Whereas the sharecroppers must pay for the means of production.

\subsubsection{Source of Labor}

The source of labor is related to the number of dependents of the farmer family. If the number of family members is large, then there is an opportunity to use labor in the family. Workers in starfruit farming, both labor in the family and workers outside the family, are needed to carry out activities such as: garden sanitation, fertilization, spraying, packaging and thinning. In the Laris Jaya II Farmer Group, workers in the family are generally needed when conducting garden sanitation, fertilization, and pruning with an average number of workers in the families involved as many as 2 people who are the heads of families and wife. Furthermore, the majority of starfruit farmers use workers outside the family and only 5 farmers use labor in the family for the whole starfruit farming activities. Out-of-family workers will be needed a lot when wrapping and thinning as well as harvesting. The average workforce outside the family is needed when packing and thinning as many as 4 people, while when harvesting only 1-2 people.

\subsection{Starfruit Development Program}

Starfruit is an icon of Depok City that has been launched since 2007. The declaration is based on the potential of starfruit that can prosper the farmers in Depok City. For this reason, in line with its stipulation in July 2009, there were various programs and activities carried out by the Depok City Government and the Association of Dewa Starfruit Farmer in achieving the aim of establishing starfruit as an icon of Depok City. The description of the starfruit development programs is:

\subsubsection{Starfruit Development Program by Depok City Government}

- Human Development Index Competition Funding Program (PPK-IPM)

According to Ms. Nuraini Widayati, Head of Horticulture in 2000 - 2008 and also a pioneer so that the city of Depok will take part in this program, mentioning that to obtain the funding program, the city government submits it in the form of a proposal. This proposal on the purchasing power field focuses on increasing the potential of Depok City starfruit. The program activities include: strengthening the image of starfruit, increasing productivity and quality, developing markets and marketing, and developing processing industries.

- Pioneer of Village Development Program (PMD)

Based on PMD Technical Guidelines (2010), mentioning this program as an effort to increase added value and optimal benefits for farmers so that they can overcome the fundamental problems faced by farmers, such as lack of access to sources of capital and weak institutional farmers.

- Featured Urban Agriculture Program

- Providing starfruit seeds to farmers and the wider community which can be obtained free of charge at Cipayung Seed Garden, Depok.

- Facilitation of starfruit marketing by participating in national fruit exhibitions such as National Flori and Flora Week activities.

- Optimization of starfruit gardens through the implementation of garden certification and registration.

- Training on post-harvest and processing of crop products.

\subsubsection{Starfruit Development Activity by Depok Starfruit Farmers Association (APEBEDE)}

- Joint marketing activities, with the aim of facilitating farmers who do not yet have a market.

- Land mapping activities and the addition of starfruit trees around the riverbank. This activity is still in the work plan.

The results of the study show that the benefits of the starfruit development program have been felt by farmers. So that the starfruit farming in the farmer group is still ongoing despite the many problems of land conversion in Depok City. But unfortunately, there is assistance from the PPK-IPM program that is currently in poorly maintained conditions, such as a water reservoir built with the aim of overcoming the limited water discharge during the dry season. 


\subsection{Analysis of Farmer Income from Starfruit Farming}

\subsubsection{Cost Analysis of Starfruit Farming}

Production costs taken into account in starfruit farming consist of fixed costs and variable costs. Fixed costs are costs incurred by farmers without being related to the number of starfruits produced such as: land tax, tree rent, and depreciation. Meanwhile, variable costs are costs incurred by farmers whose amount will affect the amount of starfruit production directly, such as: gasoline, fertilizer, pesticides, and labor.

According to Munigar, Erni Siti (2009), the agribusiness system of Dewa star fruit in Depok City has not been fully integrated vertically. Provision of farming inputs in the form of fertilizers and medicines becomes very burdensome costs for farmers in the procurement and distribution subsystem production facilities.

The average number of starfruit trees cultivated in the Laris Jaya II Farmer Group was 41 trees with an average age of 10.67 years of starfruit trees classified as yielding plants. So, the average total production cost in starfruit farming in one harvest season is IDR 3,422,620.01 (Table 2).

\begin{tabular}{|c|c|c|}
\hline Ownership Status of Starfruit Tree & Description & Amount (IDR) \\
\hline \multirow[t]{5}{*}{$\begin{array}{c}\text { Owner } \\
\text { (39 Trees) }\end{array}$} & $\begin{array}{lc}\text { Fixed Costs: } & \begin{array}{c}\text { Land Tax } \\
\text { Depreciation }\end{array}\end{array}$ & $\begin{array}{l}366,251.52 \\
179,399.06\end{array}$ \\
\hline & Total Fixed Costs & $545,650.59$ \\
\hline & $\begin{array}{c}\text { Fertilizer } \\
\text { Pesticides } \\
\text { Labor }\end{array}$ & $\begin{array}{c}55,800.00 \\
1,041,000.00 \\
474,000.00 \\
830,000.00 \\
\end{array}$ \\
\hline & Total Variable Costs & $2,400,800.00$ \\
\hline & Total Production Costs & $2,946,450.59$ \\
\hline \multirow[t]{5}{*}{$\begin{array}{l}\text { Tenant } \\
\text { (53 Trees) }\end{array}$} & Tree rent & $\begin{array}{l}435,092.19 \\
245,235.25\end{array}$ \\
\hline & Total Fixed Costs & $680,327.43$ \\
\hline & $\begin{array}{lc}\text { Variable Costs: } & \text { Gasoline } \\
& \text { Fertilizer } \\
& \text { Pesticides } \\
& \text { Labor } \\
\end{array}$ & $\begin{array}{c}48,000.00 \\
1,228,333.33 \\
574,666.67 \\
3,326,666.67 \\
\end{array}$ \\
\hline & Total Variable Costs & $5,177,666.67$ \\
\hline & Total Production Costs & $5,857,994.10$ \\
\hline \multirow{5}{*}{$\begin{array}{l}\text { Sharecropper } \\
\text { (40 Trees) }\end{array}$} & Depreciation & $266,093.00$ \\
\hline & Total Fixed Costs & $266,093.00$ \\
\hline & $\begin{array}{l}\text { Gasoline } \\
\text { Fertilizer } \\
\text { Pesticides } \\
\text { Labor }\end{array}$ & $\begin{array}{c}96,000.00 \\
771,667.67 \\
541,000.00 \\
1,693,333.33\end{array}$ \\
\hline & Total Variable Costs & $3,102,000.00$ \\
\hline & Total Production Costs & $3,368,093.00$ \\
\hline
\end{tabular}

Table 2: Average Production Costs of Starfruit Farming per Harvest Season Based on Ownership Status of Starfruit Trees

Based on the data in Table 2, the largest percentage of total production costs for starfruit farming per harvest season is spent by tenant farmers. This is influenced by the number of average starfruit trees cultivated by tenant farmers. So that it requires more labor. Furthermore, the most production costs incurred in starfruit farming are to pay wages for workers outside the family with working hours starting at 07.00-17.00 with break hours at 11.30-13.30. The daily wages paid ranging from IDR 45,000 - IDR 70,000. This difference in wage ranges is based on the agreement of farmers and workers with choices if without food, coffee and cigarettes provided then the wages are IDR 70,000 / day. If food, coffee and cigarettes are provided, the wages paid for labor are IDR 45,000 - IDR 60,000 per day. The workforce is most needed when packaging and thinning activities. According to Yani, Diarsi Eka (2013), most group members have the ability to use production facilities, which include the ability to use quality seeds, fertilizer use, and the use of pesticides.

\subsubsection{Production and Revenue of Starfruit Farming}

Farmer's revenue from starfruit farming is calculated by multiplying the amount of starfruit production with the selling price. The average number of starfruits produced in this farmer group in one harvest season is 1,320.48 $\mathrm{kg}$ with the average number of starfruit trees cultivated are 41 trees with average age of 10.67 years. The average starfruit productivity in this farmer group in one harvest season is $34.27 \mathrm{~kg} /$ tree. If on average there are five starfruits in one kilogram, then the average starfruits produced is 171 fruits/tree/ harvest season. According to Sari, Risti Lia (2017) concludes that the magnitude of the risk in starfruit farming is due to an attacking disease namely fruit flies, mosquitoes, crusts and parasites. The risks and uncertainties experienced by starfruit farmers such as diseases/ pests and extreme weather conditions, namely the existence of a long dry season that causes starfruit to fall out and the taste is not sweet. 
All members of farmer groups currently sell their starfruit to middlemen with a unit of sale per kilogram or per fruit. In addition, the sale of starfruit to middlemen is based on the rut system and some are based on grading. The average selling price of starfruit for units per kilogram with or without grading can be seen in Table 3 .

\begin{tabular}{|c|c|c|c|c|}
\hline $\begin{array}{c}\text { Ownership Status of } \\
\text { Starfruit Tree }\end{array}$ & $\begin{array}{c}\text { Production } \\
\text { Result }\end{array}$ & Amount (Kg) & $\begin{array}{c}\text { Selling Price } \\
\text { (IDR) }\end{array}$ & $\begin{array}{c}\text { Value } \\
\text { (IDR) }\end{array}$ \\
\hline Owner & Grade A & 349.47 & $5,500.00$ & $1,970,133.33$ \\
(39 Trees) & Grade B & 43.87 & $4,750.00$ & $191,266.67$ \\
& Grade C & 40.00 & $2,500.00$ & $100,000.00$ \\
& Without Grade & 826.00 & $5,166.67$ & $4,296,666.67$ \\
\cline { 2 - 5 } & Grade A & $1,233.33$ & $6,833.33$ & $8,456,066.676$ \\
\hline Tenant & Grade B & 213.33 & $4,666.67$ & $940,000.67$ \\
(53 Trees) & Grade C & 33.33 & $3,000.00$ & $100,000.00$ \\
& Without Grade & - & - \\
\cline { 2 - 5 } & Trade A & 433.33 & $5,500.00$ & - \\
\hline Sharecropper & Grade B & 133.33 & $4,000.00$ & $5,333,3333.33$ \\
(40 Trees) & Grade C & 333.33 & $3,500.00$ & $1,166,66.67$ \\
& Without Grade & 566.67 & $5,000.00$ & $2,833,333.33$ \\
\cline { 2 - 5 } & \multicolumn{3}{|c|}{ Total Revenue } \\
\cline { 2 - 5 } & Total Revenue & $6,866,666.67$ \\
\hline
\end{tabular}

Table 3: Average Number of Production and Revenue from Starfruit Farming Per Harvest Season Based on Ownership Status of Starfruit Tree

Based on Table 3, the average revenue of farmers who sell starfruit without grading is less than the sale of starfruit with grading. This condition is also supported by the selling price of starfruit without grading which is lower than the selling price of starfruit with grading. The farmers' revenue from the sale of starfruit with grading is IDR 3,549,571.43. Whereas farmer revenue from the sale of starfruit without grading is IDR 3,473,809.52. Thus, there is a difference in revenue of IDR 75,761.90 / harvest season among farmers who sell starfruit with grading and those who do not. Furthermore, based on the mastery status of starfruit trees, the tenant farmers have the biggest revenue. This is affected by the higher amount of starfruit trees that are cultivated by tenant farmers so that the production is even more than the farm owners and sharecroppers.

\subsubsection{Income and $\mathrm{R} / \mathrm{C}$ of Starfruit Farming}

The net income of farmers from starfruit farming in one harvest season is the difference between all revenue from starfruit sales and the production costs incurred during one harvest season or four months. The results of the analysis show that the highest income of starfruit farmers is in the status of tenants (IDR 3,648,672,570; then the farm owners (IDR $3,611,616.08$ ), and the lowest income is sharecroppers (IDR 1,522,116.93).

Base on Nugraha, Achmad Tjahja and Gunawan Prayitno research (2011), show that by applying track analysis model, exogenous variables, including Land Area (X1), Institution (X2), Human Resource (X3), Technology (X4), and Information System (X5), have indeed influence on the change of Income (Y) variable amounting 94.6\%.

\begin{tabular}{|c|c|c|}
\hline Ownership Status of Starfruit Tree & Description & Amount (IDR) \\
\hline \multirow{3}{*}{$\begin{array}{c}\text { Owner } \\
\text { (39 Trees) }\end{array}$} & Total Revenue & $6,558,066.67$ \\
\cline { 2 - 3 } & Total Production Costs & $2,946,450.59$ \\
\cline { 2 - 3 } & Net Income & $3,611,616.08$ \\
\cline { 2 - 3 } & R/ C & 2.23 \\
\hline Tenant & Total Revenue & $9,506,666.67$ \\
\cline { 2 - 3 } & Total Production Costs & $5,857,994.10$ \\
\cline { 2 - 3 } & Net Income & $3,648,672.57$ \\
\cline { 2 - 3 } & R C & 1.62 \\
\hline \multirow{4}{*}{$\begin{array}{c}\text { Sharecropper } \\
\text { (40 Trees) }\end{array}$} & Total Revenue & $6,866,666.67$ \\
\cline { 2 - 3 } & Total Production Costs & $3,368,093.00$ \\
\cline { 2 - 3 } & Income & $3,555,240.33$ \\
\cline { 2 - 3 } & Income of Tree Owner (58\%) & $1,999,127.40$ \\
\cline { 2 - 3 } & Income of Sharecroppers (42\%) & $1,522,116.93$ \\
\cline { 2 - 3 } & R/ C & 2.04 \\
\hline
\end{tabular}

Table 4: Average Income and R/ C of Starfruit Farming in the Laris Jaya II Farmer Group Per

Harvest Season Based on Tree Ownership Status

Based on Table 4, the average R / C value in the Laris Jaya II Farmer Group is 2.05 so that the starfruit farming done is said to be profitable. Furthermore, the greatest $\mathrm{R} / \mathrm{C}$ value based on the mastery status of starfruit trees is the farm owner. This is because the tree owner directly involves in his starfruit farming so that it can reduce production costs, especially labor costs outside the family. 


\subsection{Contributions of Farmers' Income from Starfruit Farming}

The contribution of farm income is the percentage of the contribution of income from a particular type of farming to total family income, both from businesses in the agricultural sector and outside the agricultural sector. As members of farmer groups and conducting farming in urban areas, making contribution of starfruit farming income is less than doing work outside the agricultural sector (Table 5).

However, starfruit cultivated in the city of Depok gets more attention from the city government through the establishment of starfruit as a city icon. This stipulation has an impact on increasing the selling price of starfruit and the assistance provided through various existing starfruit development programs. So that in the midst of the problem of the conversion of agricultural land in urban areas today, this makes starfruit farming continue even though its contribution is less than the contribution of income from outside the agricultural sector. The description of the contribution of each source of income for the farmer family is shown in Table 5.

\begin{tabular}{|c|c|c|c|}
\hline No. & Source of Income & Value (IDR) & Percentage (\%) \\
\hline 1. & Starfruit Farming & $3,318,409.41$ & 36.63 \\
\hline 2. & Non-starfruit Farming & $224,541.03$ & 2.48 \\
& - Spinach & $63,741.94$ & 0.70 \\
& - Kale & $62,275.28$ & 0.69 \\
& - Banana & $40,476.19$ & 0.45 \\
& $-\quad$ Guava & $6,380.95$ & 0.07 \\
\hline 3. & Corn and Sweet Potatoes & $51,667.67$ & 0.57 \\
& Outside Agricultural Sector & $5,516,190.49$ & 60.89 \\
& - Cake selling & $295,238.10$ & 3.26 \\
& - Breeder & $657,142.86$ & 7.25 \\
& - Seller & $76,190.48$ & 0.84 \\
& Construction worker & $1,773,333.33$ & 19.58 \\
& - Security & $571,428.57$ & 6.31 \\
& - School keeper & $490,476.19$ & 2.10 \\
& - Teacher & $200,238.10$ & 5.47 \\
& - Freelance & $76,190.00$ & 2.48 \\
& - Housemaid & $857,142.86$ & 0.84 \\
& Private employees & $323,809.52$ & 9.46 \\
\hline & - Odd jobs & $9,059,140.93$ & 3.57 \\
\hline
\end{tabular}

Table 5: Contributions of Starfruit Farming Income to Farmers Family Income per 4 Months

Based on the data in Table 5, it shows that the contribution of farmers' income from starfruit farming is 36.63 percent. That is, the contribution of farmers' income from starfruit farming is only 36.63 percent of the income of the farmers' family and is actually lower than the income of farmers from outside the agricultural sector with a contribution of 60.89 percent. However, starfruit which is designated as an icon of Depok City still plays a bigger role compared to other commodities cultivated by farmers in the Laris Jaya II Farmer Group. Furthermore, the contribution of farmers' income from starfruit farming to family income based on tree mastery status is also below 50 percent (Table 6).

Based on Table 6, the contribution of starfruit farming income to tenant farmers is the largest, in proportion to the amount of production and mastery of trees that are also the most. However, seen from the income of the farmer's family based on tree mastery status, the farm owner has the largest family income. This is influenced by the income from the starfruit farming is less, so with the aim of maximizing family income, the farm owners also do work outside the agricultural sector, whose income calculated based on take home pay, shows a greater contribution. The majority of livelihoods outside the agricultural sector that are carried out by the farm owners are as construction workers

\begin{tabular}{|c|c|c|c|}
\hline $\begin{array}{c}\text { Ownership Status of } \\
\text { Starfruit Tree }\end{array}$ & $\begin{array}{c}\text { Starfruit Farming Income } \\
\text { (IDR) }\end{array}$ & $\begin{array}{c}\text { Total Family Income } \\
\text { (IDR) }\end{array}$ & $\begin{array}{c}\text { Contributions } \\
\text { (\%) }\end{array}$ \\
\hline Owner & $3,611,616.08$ & $9,319,306.85$ & 38.75 \\
\hline Tenant & $3,648,672.57$ & $7,522,005.90$ & 48.51 \\
\hline Sharecropper & $1,522,112.93$ & $9,295,446.27$ & 16.37 \\
\hline Average & $3,318,409.41$ & $9,059,140.93$ & 36.63 \\
\hline
\end{tabular}

Table 6: Contributions of Starfruit Farming Income to Farmers'

Family Income Based on Tree Ownership Status

\subsection{Problems of Farmers in Increasing Income from Starfruit Farming}

In the Laris Jaya II Farmers Group, there are some farmers who claim that starfruit farming is not easy. To support their statement, there were farmers who said the term that "caring for starfruit trees is equal caring for babies".

Farmers also find various obstacles that affect the productivity of starfruit trees and also have an impact on their current income. The problems faced by farmers in increasing their income from starfruit farming are as follows: 


\subsubsection{Production Aspect}

Problems in the production aspects are related to the means and production facilities used by farmers in the cultivation process which will directly affect the amount of starfruit produced. The results showed that 47.62 percent of farmers experienced problems based on aspects of production. The problems of this aspect of production are: a) the difficulty of controlling planthopper pests, b) the limited flow of water during the dry season, c) the narrowness of starfruit farming due to land conversion.

\subsubsection{Capital Aspect}

Capital is part of the factors of production to generate income to the owner. This capital problem is always the main reason for the low income of farmers and 52.38 percent of farmers in this farmer group agree to this. The form of capital problems experienced by members of this farmer group is the limited amount of finances of farmers. Even though the members of the farmer group are said to be active in receiving assistance from various starfruit development programs so that they should no longer experience capital constraints.

According to the results of research from Citra Sari (2011) regarding the effect of production credit from PKBL program on the income of Dewa Starfruit farmers showed that the production credit did not have an impact on increasing farmers' income because the capital assistance was more used for household needs than for capital of Dewa Starfruit farming. So, in addition to the limitations of personal capital, farmers also do not have good financial arrangements resulting in irregularities in farming loans.

\subsubsection{Marketing Aspect}

Marketing problems were raised by 19.05 percent of farmer group members as a factor that inhibits farmers from increasing the income of starfruit farming. The form of marketing constraints experienced by farmers today is the sale of starfruit to middlemen because the Marketing and Processing Union of Dewa Starfruit (PKPPBDD) has not been operating since 2010.

Farmers who sell starfruit to middlemen seen as an obstacle because the selling price of starfruit is low, especially during the harvest, and the price offered by middlemen will be even lower. In addition, at the time of the harvest there are crops that are not accommodated by middlemen. To help farmers get out of this problem, there is Depok Starfruit Farmers Association (APEBEDE) institution that can accommodate farmers' crops in joint marketing activities. However, because the payment system by APEBEDE, which does not cash, makes farmers prefer middlemen because they are also pushed by needs. In the Laris Jaya II Farmers Group, only group leaders joined the joint marketing activities with APEBEDE.

\subsubsection{Institutional Aspect}

Institution is a supporting tool for the agribusiness subsystems. The existence of this institution greatly supports farmers in conducting their farming in terms of production, capital access, and marketing. However, as many as 19.05 percent of farmer group members stated that institutions were a problem in increasing their income from starfruit farming. The form of the problem is that the marketing agency (PKPPBD) is not operating, there is no scheduling in groups such as scheduling in using production facilities (e.g. lawn mowers and power sprayers) given in limited quantities, and extension activities that are not intensive at this time because according to farmers in the Laris Jaya II Farmer Group, counseling only takes place when there is a program from the Agriculture Service. Whereas in last year, counseling was rarely carried out.

In line with the things mentioned above, Hanafi, Rita; Herlina (2015) states that the main internal factors that influence its development are the availability of natural resources and farmer groups that not yet functions optimally while the main external factors that influence are the empowerment of farmer groups and a decrease in the quality and quantity of agricultural land resources

\section{Conclusions and Suggestions}

\subsection{Conclusions}

- The average farmer family income from starfruit farming in the Laris Jaya II Farmer Group in one harvest season based on tree mastery status from the highest to the lowest are: tenant farmers (IDR 3,648,672,570); then farm owner (IDR 3,611,616.08), and the lowest is sharecroppers (IDR 1,522,116.93).

- Whereas when viewed from business feasibility, the three farmer statuses are deemed feasible to continue their business, namely the farm owner's R/ C: 2.23; tenant farmers R/ C: 1.62, and sharecroppers R/ C: 2.04 .

- The contribution of farmer income from starfruit farming to the total income of the family in a row from the highest to the lowest are: tenant farmers (48.51\%), farm owners (38.75\%) and the lowest are sharecroppers (16.37\%).

- Percentage of farmers' problems in increasing income from starfruit farming based on: a) production aspects of 47.62 percent with problems such as: difficulty controlling planthopper pests, limited water discharge during the dry season, and limited starfruit farming due to land conversion, b) capital aspects with amount of 52.38 percent with the problem of limited number of private capital of farmers and improper use of capital assistance, c) marketing aspects with amount of 19.05 percent with the problem of low selling prices of starfruit to middlemen and payment of starfruit sales to APEBEDE which is not cash, and d) institutional aspects with amount of 19.05 percent with problems such as: PKPBDD marketing institutions that are not operating, no scheduling in groups, and counseling activities that are not intensive. 


\subsection{Suggestions}

- For farmers to improve the function of farmer groups as a forum to improve starfruit farming and the welfare of farmers together such as making scheduling and recording regarding the use of capital assistance that has been received so that farmers can use assistance together, and keep up with farming knowledge and technology such as using environmentally friendly pesticides.

- The need for microcredit for the development of starfruit farming whose use is monitored so that there is no deviation in the use of credit.

- For the government to increase the role of extension services in the field and limit the conversion of agricultural land by implementing land use in Depok City based on the Depok City Spatial Plan that has been set.

\section{References}

i. West Java Central Bureau of Statistics. 2018. Horticultural Production in West Java

ii. Depok City Agriculture Service. 2007. Belimbing Profile. Depok City: Depok City Agriculture Service.

iii. Indonesian Ministry of Agriculture. 2012. Terms and Procedures for Determining Horticultural Featured Products. Accessed via: 〈http:/ / perundangan.deptan.go.id/admin/ p mentan/ Permentan\%2076-2012.pdf>

iv. Hanafi, Rita; Herlina. 2015. Feasibility Study of Tasikmadu Starfruit Farming in Tasikmadu Village, Palang District, Tuban Regency. AGRISE Journal Volume XV No. 3 August 2015.

v. Hernanto, Fadholi. 1988. Farming Science. Jakarta: Spreading Self-Help.

vi. Jiancai Pi (2013) A New Solution to the Puzzle of Fifty-Fifty Split in Sharecropping. Journal of Economic ResearchEkonomska Istraživanja, 26: 2, 141-152.

vii. Munigar, Erni Siti.2009. Role of Cooperation in Development "DEWA" Starfruit Aribusiness System. Thesis Bachelor of Agriculture, Department of Agribusiness, Faculty of Economics and Management, Bogor Agricultural University

viii. Noor, Juliansyah. 2011. Research Methodology: Thesis, Thesis, Dissertation, and Scientific Work. Issue 1. Jakarta: Kencana Prenada Media Group.

ix. Nugraha, Achmad Tjahja and Gunawan Prayitno. 2011. The Development of Agro-Tourism-Based Area for Agribusiness Superior Product of Starfruit (BelimbingDEWA) in Sawangan District of Depok, WestJava. Journal of Basic and Applied Scientific Research,1(4)299-306, 2011

x. Rodjak, Abdul. 2006. Farm Business Management. Bandung: Guratuna Library Bandung.

xi. Sari, Risti Lia. 2017. Analysis of Starfruit Farming in Betokan Village, Demak District, Demak Regency. Journal of Economics and Business. Vol 12. No; 23 of 2017.

xii. Sari, Citra. 2011. Effect of Partnership and Community Development Program (PKBL) Credit on Production and Income of Dewa Starfruit Farmers (Case: Sari Jaya Farmers Group, Depok City). Thesis Bachelor of Agriculture, Department of Agribusiness, Faculty of Economics and Management, Bogor Agricultural University.

xiii. Soekartawi. 2002. Analysis of Farming. Jakarta: University of Indonesia (UI-Press).

xiv. Soeharjo and Patong, 1973. Main Farming Joints. Department of Socio-Economic Sciences. Faculty of Agriculture, Bogor Agricultural Institute.

xv. Sugiyono. 2008. Understanding Qualitative Research. Bandung: CV Alfabeta

xvi. Suratiyah, Ken. 2006. Farming Science. Print I. Jakarta: Self-Sustaining Spreader.

xvii. Yani, Diarsi Eka. 2013. Capability of Members of Farmers Group in Utilizing Production Facilities in Starfruit Farming. Proceedings of the National Seminar on Mathematics, Science and Technology. Volume 4, 2013. 